\section{Why this matters}

deterrent to advertisers, a move supported by Which? and, it appears from recent pronouncements, by Minister of State for Justice and Civil Liberties Simon Hughes MP.

The spiralling numbers of complaints of this time last year seem to have reduced, but it is clear that work remains necessary, particularly on silent and abandoned calls and prohibited unsolicited marketing. The key will be whether a reduced threshold for monetary penalty notices of up to $£ 500,000$ is introduced. But it remains to be seen whether this becomes a reality and whether legislative draftspersons can come up with workable language for an 'irritation and nuisance' based test.

Thomas Spanyol, associate, Osborne Clarke, London

\title{
Midata initiative update
}

\section{Emma Harrington}

Journal of Direct, Data and Digital Marketing Practice (2014) 15, 350-351. doi:10.1057/dddmp.2014.32

Who: The Coalition Government

Where: UK

When: 11 March 2014

Law as stated at: 11 March 2014

\section{What happened}

The Government's midata action plan began in April 2011 with the publication of the report 'Consumer empowerment strategy: Better choices, better deals'. The idea was that consumers would be able to access their transaction and consumption data easily from service suppliers in order to empower them to make the best choice for their needs, primarily in the four core sectors of energy, mobile telecoms, current accounts and credit cards.

After the introduction of the midata concept, BIS launched a consultation in July 2012 to which the Government published a response in November 2012. The Government proposed to take forward a voluntary programme for businesses in respect of midata, but also to introduce legislation to give the Government power to impose midata. This was followed through in April 2013 with the passing of the Enterprise and Regulatory Reform Act (Sections 89-91). This gave the Secretary of State the ability to issue secondary legislation imposing a duty on suppliers to provide midata to their customers in the four key sectors referred to above (with the ability to extend this to any supplier of goods and services). 


\section{Progress report overdue}

\section{Why this matters}

Then in November 2013, the Government announced a partnership with 26 organizations in the four key sectors who have 'committed to working ... with the Government to achieve the midata vision' and that a number of consumer groups and regulators are working with midata to represent consumers' interests.

The Government also promised that it would make a further announcement about progress in March 2014. So far, none has been forthcoming, but in a recent Parliamentary debate, Stella Creasy MP commented that the midata scheme "has struggled to have any impact for a simple and obvious reason: companies have little incentive to release commercial data that could convince a customer to go elsewhere'. Indeed, making it easy for a customer base to move suppliers is unlikely to be a key message that marketers would wish to support.

Furthermore, companies apply significant resources to their customer and marketing databases and therefore passing such data onto new suppliers may devalue this investment — as stated in an opinion given by a BIS spokesman to BBC News: 'The big supermarkets are reluctant, worried that the investment they have made in data analysis may be undermined if they give power to individuals' (http://www.bbc.com/news/ technology-19331302).

The main aims of the midata initiative are: (i) to boost competition to fuel innovation and better service; (ii) to enable businesses to provide better data services and have better dialogue with their customers; and, importantly, (iii) to give consumers greater control over their data to empower them to find the best service supply deal.

However, in light of the concerns raised in Parliament and by the BIS spokesman, perhaps the absence of any further update from the Government suggests reduced enthusiasm for taking this project forward. In the recent debate, Creasy urged amendments to the Consumer Rights Bill currently going through Parliament to breathe new life into the initiative. It remains to be seen whether her suggestion will be taken up or whether this grand consumer empowerment project has run into the sand.

Emma Harrington, solicitor, Osborne Clarke, London 